Original Article

Received/Accepted

Dates

09.08.2021/10.09.2021

DOI

10.52096/jsrbs.6.1.7.13.25
Journal of Social Research and Behavioral Sciences

Sosyal Araştırmalar ve Davranış Bilimleri Dergisi

ISSN:2149-178X

Volume: 7 Issue: 13 Year: 2021

\title{
Okul Yöneticilerinin Eğitim Yönetiminde Toplam Kalite Yönetimi Uygulanmasına Önderlik Etme Süreçleri
}

\author{
Zeliha Dündar \\ Ĕ̆itim Yöneticisi \\ Millî Eğitim Bakanlığı \\ zelihadundar1@gmail.com \\ ORCID:0000-0001-5997-9600
}

\section{Özet}

Milli Eğitim Bakanlığı okulda, hatta sınıfta kalitenin öneminin farkında olarak yirmi yıldır Toplam Kalite Yönetimi Uygulama Projesi'ni gerçekleştirmektedir. Projenin okul ve kurumlar üzerinde yaptığ1 etki ve var olan durum, çalışmalarda harcanan emek açısından önemlidir. Toplam Kalite Yönetiminin çağdaş katılımcı yönetim anlayışında bütün kamu kurumlarında olduğu gibi Milli Eğitim Sistemimizde de alışma ve uygulama süreci yaşanmıştır. Eğitim programlarının değişimi, öğrenci merkezli eğitim programlarının uygulanması da TKY'nin uygulanması sürecinde olumlu bir gelişmedir. TKY felsefesini benimsemiş lider yöneticilerin bulunduğu, sürekli gelişmenin hedeflendiği, küçük ama devamlı ileriye doğru adımların atıldığı, tam katılımın sağlandığı bir çalışma ile Toplam Kalite Yönetimi uygulamalarının başarıya ulaşmaması mümkün değildir.

Anahtar Kelimeler: Eğitim Yönetimi, Toptan Kalite Yönetimi, Türk Eğitim Sistemi.

\begin{abstract}
The Ministry of Education as a school, or even aware of the importance of quality in the classroom for more than 10 years of Total Quality Management Implementation Project realized. There are schools and institutions, its impact on the project and the situation is important in terms of labor spent on studies. Total Quality Management in all public institutions, as well as contemporary participatory management approach and implementation of the national education system in the process of habituation occurred. Exchange of training programs, the implementation of student-centered educational programs is a positive development in the process of implementation of TQM. Where leading executives adopted the philosophy of TQM,
\end{abstract}


continuous improvement targeted, small but continuous steps were taken forward, with one study achieved full participation is not possible to reach the success of Total Quality Management practices .

Key Words: Education Management, Total Quality Management, Turkish Education System.

\section{Giriş}

Bilim ve teknolojinin yaşamın her alanında hızla gelişip, değiştiği çağımızda, eğitilmiş, nitelikli insan gücü, en önemli faktör olmuştur. $\mathrm{Bu}$ güç, toplumlararası arenada ise büyük bir silah durumundadır. Dünya kaynaklarının daha verimli kullanımı, yaşamın devamlılığı, niteliği, toplumların hayatta kalabilme başarısı bu yeterliklere sahip insan gücünü yetiştirmeye bağlı duruma gelmiştir. Eğitim, insan yaşamının olmazsa olmazı olmuştur. İnsan yaşantısını bu kadar direk ve net bir şekilde etkileyen eğitimin nasıl yapılacağ 1 ise devletlerin eğitim sistemlerini oluşturmuştur. Artık gelişme ve kalkınmanın temeli olan eğitim, dünya pazarında ayakta durabilmek, rekabet edebilmek için geliştirilmesi gereken bir olgu durumundadır. İnsanlar yaşamın hızlı değişimi karşısında uyum sorunu yaşamakta ve yaşamlarını destekleyecek, öğrenme gereksinimlerini karşılayacak yapılanmalar talep etmektedir. Bir zamanlar sadece üretim sektörünün temsil ettiği kalite kavramı artık günümüzde yaşamın her alanında bir ihtiyaç haline gelmiştir. Eğitim de bu anlamda kalite arayışının başında gelmeye başlamıştır. Bu durumun bilinci ile Milli Eğitim Bakanlığı (MEB) birçok eğitimi geliştirme çalışması başlatmıştır. Bu gelişmenin temelinde Milli Eğitimi Geliştirme Projesi yatmaktadır.

Milli Eğitimdeki kalite çalışmaları, Toplam Kalite Yönetimi Yönergesi ile tüm birimlere ulaştırılmış olan MEB Personel Genel Müdürlüğü Yönetimi Geliştirme Dairesi Başkanlığının (YÖDGED) TKY uygulamaları ile ilgili genelgeleri ve uygulamaların taşraya yayılmasını sağlayan projeler doğrultusunda yürütülmektedir. MEB'nın 1987 yılında başlattığg Toplam Kalite Yönetimi'ne (TKY) geçiş, Okul Gelişim Modeli ve Müfredat Laboratuar Projeleri örgüt yapısında ve eğitim anlayışında yeni bir yapılanmaya geçişin ilk basamaklarıdır. Bu doğrultuda merkez teşkilatında her birimde Kalite Kurulları ve Kalite Geliştirme Ekipleri oluşturulmuş, merkez ve taşra teşkilatı yöneticilerine eğitimler verilmiştir. Ayrıca 2001 yılının başında bakanlığın web sayfasında TKY tanımlanmış, TKY uygulamalarının gerekçesi, amaçları, sağlayacağı yararlar ve TKY uygulama projesi çerçevesinde MEB tarafından yapılanan ve planlanan çalışmaların bir özeti sunulmuştur (Meder, 2001: 11). Bu araştırma ile yaklaşık 19 yıldır temeli atılan ve halen süren 
Toplam Kalite Yönetimi çalışmalarının kurumlara etkisi, çalışmaların durumu ve her şeyden önce yönetici tutumlarının tespit edilmesi amaçlanmıştır.

TKY, sürekli gelişme ve iyileşmeyi bir örgüt kültürü haline getirmeye çalışan bir felsefe olduğu için değişimin uzun soluklu olması beklenen bir durumdur. Ancak çalışmaların üzerinden uzun bir süre geçmesine rağmen birçok kurumda Toplam Kalite Yönetimi çalışmaları istenilen ve beklenen düzeyde gitmemektedir. Bu çalışmalarda kilit rol oynayan kurum yöneticilerinin TKY felsefe ve çalışmalarını benimseme durumlarının çalışmaları direk etkileyeceği düşünülmektedir.

\section{Toplam Kalite Yönetimi}

Geçmişte genellikle çok lüks anlamında algılanan kalite kavramı birdenbire ortaya çıkmış bir kuram geliştirme veya iyileştirme yöntemi değildir. Genel olarak istenen bir ürün veya hizmetin belirli kalite güvencesi ile beklenene uygun olarak sunulması ve bundan yararlananların memnuniyet duyması anlamına gelir. Eskiden "en güzel”, "en iyi”, "en büyük" gibi sıfatlarla tarif edilen kalite kavramı, bugün klasik anlamından daha farklı olarak sadece ürün veya hizmetin kalitesi olmaktan çıkmış, yönetimin kalitesi anlamında daha geniş olarak kullanılmaya başlanmıştır (Gülsoy, 2007: 47).

M.Ö. 2150 tarihli Hammurabi Kanunları'nın 229. maddesinde “Bir inşaat ustasının inşa ettiği bir ev, ustanın yetersizliği ve işini gereği gibi yapmaması nedeniyle yıkılarak ev sahibinin ölümüne yol açarsa o usta öldürülecektir." olgusu kalite kavramına verilen önemi ilkel bir şekilde de olsa anlatmaktadır. Phoenician muayene görevlilerinin hatalı üretim yapanların elini keserek cezalandırmaları da benzer biçimde kalite anlayışını yansıtmaktadır. Osmanlı Devleti'nde ise esnaf loncaları kalite anlayışının yerleştiği kurumlar olarak göze çarpmaktadır. Ustalar, hem eğitmen hem de muayene görevlisi idiler. Onlar ticareti, ürünlerini ve müşterilerini çok iyi tanıyorlardı ve yaptıkları iş ile birlikte kaliteyi inşa ediyorlardı (Özdemir, 2007: 196). Ustalar yaptıkları işten ve başkalarını kaliteli iş yapmaları için eğitmekten gurur duyuyorlardı. Yönetim, ağırlık ve ölçü standartları oluşturmuştu. Loncalarda "iş ahlakı" ile ilgili düzenlemeler de vardı. Lonca sisteminde usta çırak ilişkileri dolaysız bir nitelik taşımaktaydı. Çırak belirli safhalardan geçtikten sonra kalfa ve ustallğa yükselmekteydi ve her yükselişte kendine özgü merasimler yapılmaktaydı. Bu merasimler hem güdüleme, hem de kimin ne seviyede olduğunu gösterme açısından önemliydi. Böylece "konunun uzmanlarına iş yaptırılmış" olmaktaydı. Ayrıca usta, 
yerine adam yetiştirmek zorundaydı. Lonca sisteminde işçi, üretim sürecinin her aşamasında çalıştığı için "işin tümünü görebilmekte" ve hammaddeden başlayarak mamulün bitimine kadar her konuyu bilmekteydi. Bugün de aynı amaçla "iş rotasyonu" ve "iş zenginleştirme" yöntemleri uygulanmaktadır (Yeşilbayır, 2007: 6-7).

Toptan Kaliteyle ilgili yapılan incelemelerde genellikle nihai ürün ya da hizmetin kalitesi algılanmış fakat daha sonraları bu görüşün yetersiz olduğu anlaşılmıştır. Masaaki Imai’ye göre, kaliteden söz edildiğinde, akla ilk gelen genellikle ürün kalitesi olmaktadır. Oysa bu doğru değildir. İşin üç yapıtaşı vardır: Donanım (hardware), uygulama kuralları (software) ve insan (humanware). Kalite insanla başlar. Donanım ve uygulama kurallarından, ancak insan doğru yerine yerleştirildikten sonra söz edilebilir (Çetin ve diğerleri, 2001: 216).

Sözcük anlamı olarak kalite, Latince "Oulitas" demek olup bir şeyin nasıl oluştuğunu ifade eden "Oalis" sözcüğünden türetilmiştir. Başka bir ifade ile kalite; sözcük anlamı ile hangi şey için kullanılıyorsa, onun gerçekte ne olduğunu belli etmek amacını taşımaktadır (Çakıl, 2006: 3). Bu açıdan bakıldığında kalite ne bir fikirdir, ne de bir maddedir. Fakat bu ikisine birden bağlı bir kavramdır (Halis, 2000: 42). Bilim adamları ise kalite kavramının gelişimini incelemişler ve sonuç olarak herkesin üzerinde uzlaştığı bir anlamı bulunmadığı kanaatine varmışlardır (Çakıl, 2006: 3).

Türkmen (2006: 17)'e göre, kalite ile ilgili yapılan tanımların bazıları ise şöyledir;

- Toptan Kalite, bir ürün ya da hizmetin değeridir,

- Toptan Kalite, önceden belirlenmiş bulunan özelliklere uygunluktur,

- Toptan Kalite, ihtiyaçlara uygunluktur,

- Toptan Kalite, kullanıma uygunluktur,

- Toptan Kalite, eksikliklerden kaçınmaktır,

- Toptan Kalite, müşteri beklentilerini karşılamak veya onların ilerisine geçmektir.

Yıllara göre değişen kalite anlayışı günümüzde daha çok, "ürünün kullanıldığı sürece çokça fayda sağlaması" şeklinde bir değişme göstermiştir. Kalite ile ilgili tüm faaliyetlerin insan tarafından etkilendiği görülmektedir. Yaşamımızın her alanında yer alan bir olgu olarak kalite, ister sanayi sektöründe olsun ister hizmet sektöründe, devamlı gelişen, kimi zaman yaratılan, kimi zaman ulaşılmak istenen bir kavramdır. Kalitenin yaratılması ise ancak, o ölçüdeki vasıflara sahip insanlarca gerçekleştirilir (Ensari, 2009: 19-20).

Tıpkı kalite kavramı gibi Toplam Kalite Yönetimi (TKY) de kesin bir tanıma sahip değildir. Bunun yerine kaynaklarda TKY'nin çeşitli tanımlamaları yapılarak farklı özellikleri ön plana 
çıkarılmıştır. Örneğin, Gülsoy (2007: 16)’a göre, “TKY, küresel rekabet koşullarında işletmelerin varlıklarını sürdürmelerini sağlayacak bir yönetim modeli olarak geliştirilmiş̧tir. Kalite, en kısa biçimde müşteri tatmini olarak tanımlanmaktadır. TKY ise firmanın kaliteye ilişkin müşteri beklentilerini karşılayan bir yönetim sürecidir". Dökmen (2009: 262) de "TKY'nin dört temel özelliği olarak, müşteri memnuniyetini, süreçlerin sürekli iyileştirilmesini, kurumda kalite kültürünün oluşturulmasını ve ekonomik etkinlikleri” saymaktadır.

TKY, işgörenlerin ve müş̧erilerin ihtiyaç, istek ve beklentilerinin en üst düzeyde karşılanması ve işletme mükemmelliğinin sağlanarak, topluma hizmet edilmesi amacıyla, tedarik aşamasından başlayarak, sıfır hata prensibiyle ürünün veya hizmetin son müşteriye kadar sunulması süreci içerisinde, mükemmelliğe ulaşmayı ve bunu sürekli kılmayı, kurumsal eğitim ve işbirliği içerisinde gerçekleştiren ve bu yolla rakiplerine rekabet üstünlüğü sağlamayı amaçlayan bir yönetim anlayışıdır (İnce, 2008: 1). TKY ile kurumlar, ürününü veya hizmetini alacak olan alıcının şimdiki veya gelecekteki ihtiyacını karşılayacak nitelikte ve nicelikte ürün/hizmet üretmek için, tüm kurumun etkililiğini en üst düzeye çıkarmayı amaçlar (Başaran, 2004: 179).

Eroğlu (2000: 169), TKY'de müşterinin önemine dikkat çekerek, kaliteden asıl beklenenin ekonomik gerçeklik olduğunu belirtir. Ona göre, pazar geliştirmek, verimliliği arttırmak ve rekabet gücünü yükseltmekle mümkündür. Bunun da en temel yolu müşteri beklentilerinin sağlıklı olarak saptanıp tam olarak tatmin edilmesidir. TKY çeşitli ögelerden oluşmaktadır. Bunlardan bazıları arasında müşteri odaklılık, edim geliştirme, sürekli süreç denetimi, süreç ve insan kaynakları yönetimi sayılabilir. TKY'de "önce insan" ve "birey kalitesi” gibi ögelerin de oluşturulması gereklidir. Bunların yanında yedi önemli aşamanın gerçekleştirilmesi de TKY için önemlidir. Bu aşamalar şunlardır (Ensari, 2009: 27):

1. Öneri-ödül sisteminin oluşturulması.

2. İstatistiksel kontrol sürecinin yaygınlaştırılması.

3. Açık kapı politikasının uygulanması.

4. Sürekli gelişimin (Kaizen) her yerde ve her zamanda uygulanması.

5. Kalite danışmanlığının benimsetilmesi.

6. Yönetici ve işgören eğitiminin gerçekleştirilmesi.

7. Kalite çemberlerinin oluşturulması.

Eğitimde TKY ilkelerini ortaya koyabilmek için sürekli gelişimin sağlanması gereklidir. Bunun için dürüstlük, sabır, ortak görüş, bağlllık ve TKY teorisi eğitim kurumlarında oluşturulmalıdır. 
Bu ilkelerin kurumda egemen kılınabilmesi için, kurum içi önemli kişilerin ve birimlerin önceden saptanması, rekabetçi ve kaliteye dayalı bir misyonun geliştirilmesi, iç değerlendirme ve kalite sistemlerinin kurulması, kurum içindeki işgörenler arası güdülenmenin artırılması, her birim için gerekli ölçünlerin belirlenmesi ve kurum içi denetim, ödüllendirme birimlerinin oluşturulması gerekmektedir (Doğan, 2003: 165-166).

Dökmen (2009: 257) ise, TKY'ye daha geniş kapsamlı bakarak TKY'nin sadece bir yönetim biçimi olmadığını, aynı zamanda bir yaşam felsefesi haline dönüştüğünü belirtir. Dökmen, insanların günlük yaşamlarında TKY felsefesini benimseyerek hem kendileri hem de diğer insanlar için daha kaliteli yaşam ortamları oluşturabileceklerini ifade eder. Ona göre kaliteli yaşamın temeli ailede atılmalı, tüm aile bireyleri ailenin yaşam kalitesinden sorumlu olmalıdır. TKY sihirli bir değnek değildir ve başarıya ulaşmanın tek bir yolu da yoktur (Şişman ve Turan, 2002: 48). TKY'nin bir yolculuk olduğu, varılacak bir yer olmadığı unutulmamalıdır. TKY ürün ve hizmetlerin sistematik gelişimi için bir metottur. Bütün çalışanları yapılanlara dâhil eden, katılımcı bir tekniktir. Tamamen müşteriye odaklanmış, işletme kültürünü oluşturan bir yönetim sistemi, kurumun var oluşuna ilişkin bir olgudur (Gülsoy, 2007: 16-17). Benzer görüşler Çağlar ve Reis (2007) tarafindan da ifade edilir.

\section{Eğitim Yönetimi’nde Toplam Kalite Yönetiminin Uygulanması}

Eğitim toplumların gelişimlerinin en temel dayanağı olarak geçmişten günümüze dek önemini koruyan bir olgudur.

Eğitim; evrenin, yerkürenin, yaşam sistemlerinin ve bilincin hikâyesini bilmek, bu hikâyede insanın rolünü tanımak olarak tanımlanabilir. Eğitimin öncelikli amacı ise, kişilerin bu geniş anlam içindeki rollerini yerine getirebilmelerini sağlamaktır. Günümüzde farklı bir dünya düzeni, küreselleşme, dünyaya açılma, yeniden yapılanma gibi değişme ve gelişmelerden söz edilirken; bu değişisme ayak uydurabilmek için eğitim yoluyla yetiştirilecek bireylerin araştıran, sorgulayan, problem çözebilen, eleştirel düşünebilen, öğrenmeyi öğrenen, bilgiyi üretebilen, yaratıcı, esnek, teknolojiden faydalanabilen, düşündüklerini kolayca ifade edebilen, takım çalışması yapabilen vb. özelliklere sahip olmaları beklenmektedir (Şen ve Erişen, 2002: 100). Bu koşullar göz önüne alındığında TKY, eğitimdeki yaratıcılığın ve modernizasyonun sağlanması için oldukça önemlidir. İkinci Dünya Savaşı’nın ardından Japonya’nın kendini tekrar inşa etmesi ile 
sistemleşen bu anlayış, 1980'lerde öncelikle sağlı ve hizmet sektörleri ile bağlantıllı endüstri işletmelerinde uygulanmaya konmuş (Gülsoy, 2007: 52), 1990'lar itibariyle de artık sanayi sektöründen farklı olarak sosyal alanda da kendini göstermeye başlamıştır (Yıldız, 2006: 34). Bu sosyal alanlardan belki de en önemlisi; bireye toplumun inanç, değer, standart, yetenek, tutum, yöneliş ve diğer davranış örüntülerini (Demirel ve Kaya, 2004: 5), kısacası toplumun kendisi için meydana getirdiği her şeyi kazandıran eğitim ve okuldur (Dewey, 2008: 23). Bu bağlamda, eğitim örgütlerinin; bilginin üretildiği, genelleştirildiği, korunduğu ve aktarıldığı örgütler olarak, sürekli yeni çalışma yollarını arayıp, uygulaması gerekir. Bunu yapabilmesi için de eğitim örgütlerinin, insanların beklentileri yönünde ve bu beklentilere cevap verebilecek yapıya kavuşturulması gerekmektedir (Gülsoy, 2007: 50).

\section{Eğitimde Toplam Kalite Yönetiminin Uygulanabilirliği}

Eğitimde kalite kavramı birçok anlamı çağrıştıran bir ifade olarak karşımıza çıkmaktadır. Çünkü eğitimin kalitesi zamanla değişir, amaçların, işlevlerin ve ortaya koyduğu ürünlerin değişikliğine bağlı olarak zaman içinde farklılaşır. Genel bir tanımla; eğitimin kalitesi, eğitimin amaç ve işlevlerini gerçekleştirme veya başarma biçimi ve derecesi olarak kabul edilebilir (Gülsoy, 2007: 61-62). Ancak eğitim örgütlerinde TKY uygulamalarının endüstri örgütlerinden çok farklı olacağı açıktır. Amaçlar, süreçler, girdiler ve ürünler yönünden okullar, endüstri işletmelerinden farklılaşmaktadır. Endüstri işletmeleri kar elde etme güdüsü içinde ürün ağırlıklı işletmeler olmasına karşın, eğitim örgütlerinin amacı bu denli basit ifade edilemez (Şişman ve Turan, 2002: 74-75). Okul dediğimiz kurumların, endüstri işletmelerinden fark1; üzerinde çalıştığ1 hammaddenin toplumdan gelen ve yine topluma giden insan oluşudur. Eğitim örgütü olan okulların informal yanı formal yanından üstündür. Ayrıca okulların etki alanları, yetki alanlarından da geniştir. Sosyal yönü ağır basan sistemler olma özelliği taşıyan okullarda yöneticiler insan ilişkilerine ağırlık vermeli, bu konuda iyi eğitim sahibi olmalıdırlar (Bursalığlu, 2005: 33). Crawford ve Shutler tarafından ifade edilen görüşe göre, eğitim örgütlerinin endüstri işletmeleri gibi ürün odaklı olması, okulların kalite göstergesi olarak öğrenci sınav sonuçlarını esas almasını gerektirir. Böyle basit bir ifade ise, eğitimin genel amaçlarına aykırıdır. Çünkü sadece sınav sonuçlarını değerlendirmek pasif, düşünme becerileri gelişmemiş, bağımsız iş yapma becerisi kazanamamış bireyler yetişmesine neden olacaktır (Şişman ve Turan, 2002: 74). 
Herhangi bir durumda kaliteye ilişkin algılama iki temel soru üzerinden cevaplanabilir; bunlardan birincisi ürünün ne olduğuna, ikincisi ise müşterilerin kimler olduğuna ilişkindir. Eğitim örgütleri açısından öğrencilerin ürün olarak kabul edilmesi yönünde önemli kuşkular vardır. İkinci olarak, hammaddeler belirli elemelerden geçirilerek sürecin girdisi olmakta, ürünler de önceden belirlenmiş niteliklere sahip olmalıdır. Böyle bir sistem eğitim örgütleri için mümkün görünmemektedir. Kısacası öğrencileri önceden belirlenmiş standartlara göre üretmek olanaksız bir durumdur (Ensari, 2003: 16-17). Ayrıca endüstri sektörlerinde üretimde kabul edilen hammaddenin değişmesi üretim şeklinin, makinenin, teknolojinin, işgücünün, yönetim anlayışının ve pazarın değişmesi söz konusu olabilir. Buna ilaveten, sayılan tüm bu değişikliklerin sayısal olarak ölçülmesi de olanaklıdır. Ancak bu tür bir ölçümü eğitimde davranış değişikliği sürecinde yapmamız zor, bazı durumlarda ise imkânsızdır (Yıldırım, 2002: 76). Sallis bu örneklere dayanarak eğitim ürününü tanımlamanın imkânsız hale geldiğini söylemektedir. Öyleyse eğitimi bir ürün olarak değil, bir hizmet olarak değerlendirmek daha yararlı olacaktır (Ensari, 2003: 17). Dahlgaard ve Kristensen'in ifade ettiği üzere; eğitim hizmetlerinde diğer sistemlerden daha fazla oranda insan kaynağına bağl1lık söz konusudur. Okullarda kalite kültürünün oluşturulabilmesi için bu kaynak etkili ve verimli bir şekilde yönetilmelidir. Etkili bir öğrenme ortamının sağlanması, işgörenlerin neyi, nasıl ve niçin öğreneceklerini bilmesi, bireysel gereksinimlerinin tanımlanması eğitimde TKY'nin başarıya ulaşması için ön koşullardır (Akbulut Taş, 2004: 10).

Eğitim kurumlan; amaçları, süreçleri, girdileri ve ürünleri bakımından endüstri örgütleri ile farkl11ıklar göstermektedir. Bu sebeple endüstri işletmelerinde başarılı uygulama örneklerine rastladığımız TKY'nin, eğitim kurumlan açısından aynı şekilde uygulanıp uygulanamayacağı pek çok araştırmaya konu olmuştur. Ancak araştırmalar neticesinde, yaşanılan sıkıntılara rağmen, eğitimde TKY'nin uygulanamayacağı gibi bir görüş öne sürülememektedir. Dolayısıyla günümüzde kabul edilen yaygın görüş; TKY'nin eğitim kurumlarında da uygulanabileceği şeklindedir. Nitekim 1990’lı yıllar itibariyle sosyal özelliği ağır basan kurumlarda uygulanmaya konan TKY’nin, eğitim kurumlarında da örneklerine rastlamak mümkündür. Milli Eğitim Bakanlı̆̆ı'nın da günümüzde baz aldığı Avrupa Kalite Vakfı (EFQM) Ödülü, eğitim kurumlarına da verilmektedir (Yıldız, 2006: 144).

Toplam Kalite Yönetimi'nin eğitim kurumlarına getireceği pek çok fayda bulunmaktadır. Bunlar arasında; öğretmen, öğrenci, eğitim yöneticileri, veliler ve diğer tüm paydaşların ortak bir vizyon ve hedef etrafinda bütünleşmeleri sağlanır. Takım çalışmaları ile paydaşlar arasındaki iletişim 
güçlenir. Farklı bakış açılarına sahip üyelerce oluşturulan kalite takımları problemlere daha etkin çözüm yolları üretebilir. Bu sayede sistemin tümünde iyileşmeler sağlanabilir. Toplam kalite mantığı çerçevesinde sadece sonuca odaklanılmaz, sistemin tüm alt süreçleri geliştirilir. Eğitimden beklentisi olan grupların memnuniyeti artar (Türkmen, 2006: 49, 51). Eğitimde TKY uygulamalarının ilk örnekleri ABD ve İngiltere'deki okullarda olmuştur. Örnek vermek gerekirse; ABD'de George Westinghouse Mesleki ve Teknik Lisesinde 1988 yılında uygulanan TKY uygulamasında okul süreçlerindeki hataları belirleme, bunları ortadan kaldırma ve okulun öğrenme ortamını değiştirme ve geliştirme gibi konular üzerinde durulmuştur (Özdemir, 2007: 523). Westinghouse lisesindeki toplam kalite uygulamaları sonucunda; öğrenciler okula ve derslere daha fazla ilgi duymaya başlamışlar, öğrencilerin okula devamsızlık oranı \% 2,1'e düşmüştür (bu oran New York genelinde \%17,2'dir). Mezunların \% 72'si üniversite ya da yüksekokula devam etmiş̧tir. Okuldaki sosyal, kültürel faaliyetler daha da artmıştır; öğrenciler satranç, bilgisayar, liderlik, matematik, optik, Asya-Afrika-Amerika kültürü gibi yeni kulüpler kurmuşlardır. Okul-aile birliği üyelerinde çok büyük artışlar olmuştur. Öğretmenler çok sayıda bölümler arası toplantı gerçekleştirmişler ve bu toplantılarda okul süreçlerindeki problemler çözülerek, işbirliği ve iletişim güçlenmiştir. Mesleki ve teknik bölümdeki öğretmenler, dokuzuncu sınıf programını ekip çalışmasıyla yeniden geliştirmişlerdir ve okula kayıt için başvurularda önemli oranda artışlar yaşanmıştır (Özdemir, 2007: 523).

Bir başka başarılı çalışma da ABD'nin Alaska eyaletinde bulunan Mt. Edgecumbe Lisesi'nde gerçekleş̧irilmiştir. Bu lisede de; okulu bırakma oranı önceki yıllara göre oldukça düşmüş, mezunların \% 68'i kolej ya da üniversiteye, \% 28'i teknik/ticaret okullarına devam etmiştir. Öğrencilerin \% 97'si aldıkları eğitimin kalitesinin, bulundukları çevredeki diğer okullardan daha iyi olduğuna inanmaktadırlar. Mezunların \% 75'i, eğitime devam etmelerinde okulun büyük katkısının olduğu kanısındadır. Mezunlarının \% 92'si çocuklarının da bu okulda öğrenim görmesini istemektedirler. Uyuşturucu ve alkol bağımlılı̆̆ önemli oranda azalmış, veli memnuniyetinde toplam kalitenin uygulanmaya başlamasından itibaren büyük artış olmuştur (Özdemir, 2007: 524). Eğitimde TKY uygulamalarına buna benzer örnekler verilebilir. Ancak sonuç olarak belirtmemiz gereken; Toplam Kalite Yönetimi ilkelerinin eğitim kurumlarına uyarlanarak, eğitim alanında da başarılı çalışmaların gerçekleştirilebileceğidir. İşte bu nedenle ülkemizde Milli Eğitim Bakanlığı, 1999 yılında bir genelge yayımlayarak taşra ve merkezde yeralan tüm okulların TKY anlayıșı ile yönetilmesini istemiştir. 


\section{Eğitimde Toplam Kalite Yönetimine Yönelik Görüşler}

TKY'ye günümüzde yöneltilen eleştirilerin, TKY'nin değişim ve idealleştirme ilkeleri, süreç merkezlilik, müşteri memnuniyeti, tam katılımın sağlanması ve takım çalışmaları üzerinde yoğunlaştığ 1 görülmektedir. Bunun yanında takım halinde çalışma ve dayanışmanın işgören örgütlenmelerini engelleyeceği, işgören kimliğinin geri plana itilmesine ve TKY ilkelerinin işgörenlerin birbiri üzerinde denetim ve baskı aracı olarak kullanılma riskine dikkat çekilmektedir (Yaşar, 2003: 64). TKY’ye yönelik eleştiriler belli başlı beş başlık altında ifade edilmiştir; idealleştirme, değişim, müşteri memnuniyeti, süreç odaklılık, takım çalışması ve katılım (Yaşar, 2003: 64, 66). Bu görüşlerin altında değişik alt görüşler mevcuttur. Bunlara değinilecek olursak; İdealleştirme: Wilkinson ve Willmott açısından Toplam Kalite Yönetimi, yapılan her türlü değişimin kendisine atfedildiği, sözel olarak çokça kullanıldığı halde anlamı tam kavranamamış bir yönetim yaklaşımıdır. TKY, oldukça soyut, ölçülemez ilkelere dayanmaktadır (Halis, 2000: 207; Yaşar, 2003: 64). Yüksek hedeflere bağlı kalınması, yüksek beklentiler doğurmaktadır. Bunun sonucu olarak başarılı olamayan hedefler personelde motivasyon ve iş doyumu kaybına yol açmaktadır. Çalışanların işten çıkarıldığı, yeni çalışanların geldiği bir kurumda sıfır hata kavramının deneyimsiz, kurum kültürüne yabancı çalışanlarca gerçekleştirilmesi zordur. Dış paydaşların kuruma yaptıkları baskı göz ardı edilmektedir. TKY'de sürekli olarak başarı vurgulanırken, başarısız olunabileceği düşünülmemektedir. Çalışanların yaratıcılıklarını sergilemesi istenirken, aynı zamanda kalite anlayışına sıkı sıkıya bağlı kalmaları bir çelişki olarak görülmektedir (Halis, 2000: 208).

Değişim: TKY ilkelerinin değişmez olduğu, evrensel nitelik taşıdığı fikri bir yanılsamadır. Ayrıca Toplam Kalite Yönetimi’nin dayandığı “Kaizen” yani küçük adımlarla ilerleme fikri günümüzün hızla değişen dünyasına uygun görünmemektedir. TKY genel olarak Japon kültür ve toplum yapısına uygun olduğu için tüm ülkelerde aynı şekilde uygulanması zordur (Yaşar, 2003: 65).

Müşteri Memnuniyeti: Müşterilerin istekleri konusunda her çalışanın fikri değişiklik göstermektedir. Dolayısıyla müşterilerin istek, beklenti ve ihtiyaçlarının tam olarak anlaşıllpp, karşılanması mümkün görünmemektedir (Halis, 2000: 209).

Süreç Odakl11ık: Toplam Kalite Yönetimi sonuçlardan ziyade süreçler üzerine yoğunlaşan bir yönetim yaklaşımıdır. $\mathrm{Bu}$ ise amaçların yetersizliği sonucu amaçlar araç haline gelmektedir. Amaçlardan sapma, süreçlerde kullanılan resim, grafik, çizelge, tablo vb. dokümanların 
çoğalmasına, yani kırtasiyeciliğe neden olmaktadır (Halis, 2000: 209).

Takım Çalışması ve Katılım: Bu noktadaki eleştiri, TKY'nin takım çalışması ilkesinin kaynakları israf ettiği yönündedir. Takım çalışmaları belli kısıtlamalara neden olmakta, tüm çalışanlar eşit derecede katılım gösterememektedir. Bir kurumda her çalışanın aynı derecede bilgiye ve yeteneğe sahip olmadığı düşünülürse, katılım konusunda hepsinin aynı performansı göstermesi beklenmemelidir. Ayrıca karar alma sürecine katılımda genelde alınmış kararlara uyma şeklinde bir eğilim gözlenmektedir. Takım halinde karar alma, takımda ayrışmalara, zaman ve para israfına neden olmaktadır. Takım çalışmalarında sorumluluktan kaçma, denetim güçlüğü ve kişisel problemler istenilen verimin alınması yolunda engel teşkil etmektedir (Halis, 2000: 209).

\section{Ĕ̈itim Sisteminin Genel Yapısl}

Eğitim sisteminin genel yapısı birkaç başlık altında toplanabilir. Bunları da kısaca şu şekilde izah edebiliriz.

\section{Eğitim Sisteminin Yasal Temelleri}

Bugünkü Türk Milli Eğitim Sistemi’nin yasal dayanağı 14 Haziran 1973 tarihinde kabul edilen 1739 sayılı Milli Eğitim Temel Kanunu'na dayanmaktadır. Bu kanuna göre Türk Milli Eğitim Sistemi başlıca iki kısımdan oluşmaktadır (Erdoğan, 2003: 14):

Örgün Eğitim: Okulöncesi, ilköğretim, ortaöğretim ve yükseköğretimi kapsayan kısımdır. Yaygın Eğitim: Örgün eğitimin dışında gerçekleştirilen her türlü planlı eğitimi kapsamaktadır. Milli Eğitim Temel Kanunu, Türk Milli Eğitimi'nin genel amaçlarını şöyle sıralamıştır (Adem, 2000: 78-79): Türk Milli Eğitiminin genel amac1, Türk Milletinin bütün fertlerini,

1. Atatürk inkılâplarına ve Anayasanın başlangıcında ifadesini bulan Türk Milliyetçiliğine bağl1; Türk milletinin milli, ahlaki, insani, manevî ve kültürel değerlerini benimseyen, koruyan ve geliştiren; ailesini, vatanını, milletini seven ve daima yüceltmeye çalışan; insan haklarına ve Anayasanın başlangıcındaki temel ilkelere dayanan milli, demokratik, laik, sosyal bir hukuk devleti olan Türkiye Cumhuriyetine karşı görev ve sorumluluklarını bilen ve bunları davranış haline getirmiş yurttaşlar olarak yetiştirmek;

2. Beden, zihin, ahlak, ruh ve duygu bakımlarından dengeli ve sağlıklı şekilde gelişmiş 
bir kişiliğe ve karaktere, hür ve bilimsel düşünme gücüne, geniş bir dünya görüşüne sahip, insan haklarına saygıll, kişilik ve teşebbüse değer veren, topluma karşı sorumluluk duyan; yapıcı, yaratıcı ve verimli kişiler olarak yetiştirmek;

3. İlgi, istidat ve kabiliyetlerini geliştirerek gerekli bilgi, beceri, davranışlar ve birlikte iş görme alışkanlığı kazandırmak suretiyle hayata hazırlamak ve onların, kendilerini mutlu kılacak ve toplumun mutluluğuna katkıda bulunacak bir meslek sahibi olmalarını sağlamak; Böylece, bir yandan Türk vatandaşlarının ve Türk toplumunun refah ve mutluluğunu artırmak; öte yandan milli birlik ve bütünlük içinde iktisadi, sosyal ve kültürel kalkınmayı desteklemek ve hızlandırmak ve nihayet Türk milletini çağdaş uygarlı̆̆ın yapıcı, yaratıcı, seçkin bir ortağı yapmaktır (Madde 2).

\section{Eğitim Sisteminin Örgüt Yapısı}

Türk Milli Eğitim Sistemi örgüt yapısı başlıca üç bölümden oluşmuştur (Başaran, 1998: 21);

1- Merkez Örgütü: MEB'i kapsayan üst sistemdir. Bu düzeyde amaç, yurt çapında milli eğitime yön veren kararlar üretmektir. Bakanlık makamı, Talim ve Terbiye Kurulu Başkanlığı, ana hizmet birimleri, yardımcı hizmet birimleri ve danışma ve denetim birimlerinden oluşmaktadır.

2- Taşra Örgütü: İl, ilçe ve yurtdışı eğitim müdürlüklerini kapsayan aracı üst sistemlerdir. Bu düzeyde amaç, üst sistemlerden gelen kararları temel sistemlere iletmek, güçlendirme hizmeti sunmak ve yetkileri dahilinde kararlar almaktır.

3- Okulöncesi, ilköğretim, ortaöğretim okullarını, yaygın eğitim merkezlerini kapsayan temel sistemler. Bu düzeyde bulunan okulların amacı; eğitim ve öğretim hizmetlerini sağlamaktır.

\section{Ortaöğretimin Tarihi Gelişsimi}

Ortaöğretim, eğitim sistemimizde 14-18 yaş grubundaki gençler için eğitim programının uygulandığı kurumlardır. bir kademeden oluşan bu kurumlarda eğitim süresi toplam dört yıldır. Ortaöğretim okullarında kesintisiz eğitim yapılır ve bitirenlere Ortaöğretim diploması verilir (Ergit, 2000: 135). Türkiye dünyanın en eski Ortaöğretim sistemi olan ülkelerinden biridir (Kaya, 2009: 96). On dokuzuncu yüzyıldan itibaren ülkemizde önemi artmaya başlayan okullar ilk kez 
1826 yılında parasız ve zorunlu hale getirilmiş̧ir. Ancak bu dönemde okulların yaygınlaşamadığ 1 görülmektedir. Ortaöğretim yaygınlaşması ilk kez Cumhuriyetin ilanından sonra 1924 anayasası ile sağlanmıştır. Ancak ülkemizde sekiz yıllık zorunlu ve kesintisiz ilköğretimin tam olarak uygulamaya geçilmesi 1997-1998 öğretim yılından itibaren olmuştur. Bundan sonra da okullaşmaya verilen önem artmıştır (Türkmen, 2006: 64). Ortaöğretim kurumlan bir toplumda

eğitimin bel kemiğini oluşturur. Öteki eğitim basamakları da bu temele dayanır. Bu temel eğitim toplumun öteki sistemlerini de olumlu veya olumsuz şekilde etkiler. Geri kalmış ülkelerde bütün vatandaşların Ortaöğretimden geçmesi ekonomik ve toplumsal kalkınma için ön koşuldur. Ortaöğretim bu önemi nedeniyle İnsan Hakları Evrensel Beyannamesi’nin yirmi altıncı maddesinde de vurgulanmıştır (Kaya, 2009: 95-96).

\section{Okul Yöneticilerinin Toplam Kalite Yönetimindeki Önderlik Süreçleri}

\section{Müfredat Laboratuar Okul Projesi}

Toplam kalite yönetimi, bugün ülkemizde Milli Eğitim Bakanlığının tüm birimlerinde yaygınlaşmasını amaçladığı bir yaklaşımdır. Milli Eğitim Bakanlığı, 19 Ekim 1999 tarihinde yayımladığı 2506 sayılı Tebliğler Dergisinde, Toplam Kalite Yönetiminin tüm devlet okullarında uygulanmasını istemektedir. TKY'nin okullarda gerçekleşmesinde “MLO Uygulamalarının Yaygınlaştırılması Yönergesi”ne göre üç aşamalı bir süreç uygulanır. Bu süreçler; ön hazırlık, uygulama ve değerlendirmeden oluşmaktadır (Türkmen, 2006: 65). Şişman ve Turan (2002: 98, 110) bu aşamaların her biri için aşağıdaki faaliyetlerin gerçekleştirilmesini önermektedir;

Ön Hazırlık:

- Eğiticilerin eğitimi

- Okul lider ve öğretmenlerinin eğitimi

- Okul kalite geliştirme grubunun oluşturulması

- Okul kalite geliştirme ekiplerinin oluşturulması

- Okul profilinin çıkarılması

Uygulama:

- $\quad$ Okul liderliği

- Okul vizyon ve amaçlarının belirlenmesi 
- Okul ve paydaşların ihtiyaçlarının belirlenmesi

- $\quad$ Okul politika ve stratejilerinin belirlenmesi

- Okul kaynaklarının harekete geçirilmesi

- $\quad$ Okul süreçlerinin yönetimi ve geliştirilmesi

Değerlendirme:

- İnsan boyutuna ilişkin sonuçlar

- Topluma ilişkin sonuçlar

- $\quad$ Genel performansa ilişkin sonuçlar.

Eğitim sistemimizde Müfredat Laboratuar Okul (MLO) uygulaması ilk kez 1994-1995 öğretim yılında faaliyete geçirilmiş̧ir. Dünya Bankası destekli bu projenin amacı; MLO'larda eğitim sistemimiz içerisinde araştırma ve geliştirme çabalarıyla ortaya konacak her türlü çalışma için pilot uygulamaların yapılmasının sağlanmasıdır. Bu modelde okul yöneticileri ve öğretmenlerine önemli yetki ve sorumlulukların verilmesi öngörülmüş, paylaşımcı, işbirliğine dayalı bir okul kültürü egemen k1lınmak istenmiştir. MLO'larda TKY anlayışı benimsenerek, danışma ve rehberliğe dayalı gelişimsel rehberlik hedeflenmiş̧ir (Şahin, 2006: 41). MLO projesinin okullarda uygulanması için geniş katılımlı Okul Gelişim Yönetim Ekipleri (OGYE) kurulmuştur. OGYE’nin içinde Okul idare temsilcisi, öğretmen, öğrenci, veli, sanayi ve ticaret odaları, sivil toplum örgütü temsilcileri yer almaktadır. Burada amaç katılımcılığı geliştirmektir (Çakıl, 2006: 69).

TKY uygulamalarının asıl hedefi okulda ve sınıfta kaliteyi yakalamaktır. Bu gerçekten hareketle taşra teşkilatına yönelik olarak, 2001 yılında hazırlanan MEB Taşra Teşkilatı Toplam Kalite Yönetimi Uygulama Projesi yürürlüğe konmuştur. Bu proje çerçevesinde TKY formatörleri yetiştirilerek kalite konusunda bilgilendirme çalışmaları taşra teşkilatında da sürdürülmektedir. Eğitimde kalitenin yakalanması ile Türkiye'de toplumsal hayatın her alanına kalitenin geleceği bir gerçektir. Yetiştirilen her öğrenci sahip olduğu kalite bilincini istihdam edileceği iş koluna taşıyabilecek veya hizmet ve mal talep ederken en önemli kriteri kalite olacaktır. Bu durumda kalitenin hayatın her alanında aranır bir olgu olması sağlanacaktır (Çakıl, 2006: 69). 


\section{Okul Yönetiminde Toplam Kalite Yönetimi Süreci}

Okul yönetiminde TKY anlayışının hayata geçirilebilmesi için ardışık birtakım eylem ve faaliyetlerin yapılması gerekmektedir. TKY, bir süreçtir ve uzun bir yolculuğa benzer. Dolayısıyla okulların akşamdan sabaha bu anlayışı okul yaşamında yerleştirebilmeleri mümkün olmayıp bu iş oldukça zaman alıcıdır. Onun için bazı eğitim örgütlerindeki TKY uygulama çalışmaları başarısızlıkla sonuçlanmakta, insanlar da bunun yaşama geçirilebilmesi konusunda umutsuzluğa kapılmaktadırlar. (Halis, 2000: 218). TKY'nin ne olup olmadığı konusunda öncelikle yetkin bir ekipten eğitim alınarak okulda bu süreci başlatacak eğitici kadronun yetiştirilmesi gerekmektedir. Dışarıdan alınacak birkaç oturumluk TKY eğitimi bu konuda yeterli olmayacaktır Uzun süreli bir eğitim hizmetinin maliyeti de yüksek olacaktır. Bu nedenle her okulun kendi eğitici kadrolarını yetiştirmesi gereklidir $\mathrm{Bu}$ süreçte yapılacak ilk iş, her okulun öncelikle bir ekibi bu amaçla yetiştirmesidir. Bu konuda danışman şirketlerden ya da ilgili alan uzmanı öğretim üyelerinden yardım alınabilir. Ancak öncelikle örgütün kendi kaynaklarını hareket geçirmesi gereklidir. (Demirci, 2008: 181).

Örgütün kendi kaynaklarından da bir lider çıkarması gerekir. Eğitsel liderlik, okulun ve yöneticinin sorumluluğu olarak görülmektedir: Oysa toplam kalite yaklaşımında liderlik, ilgili örgütteki ya da alandaki herkesin sorumluluğudur. Böyle bir yaklaşımı benimsemiş bir eğitim kurumunda da, yöneticiler, öğretmenler ve diğer çalışanlar kararlar vermekten çekinmezler; onların katkıları ve önerileri memnuniyetle karşılanır ve istenir. Ancak böyle bir eğitim kurumunun öğrencileri, herkese potansiyelinin en üst sınırına erişebilmesini sağlayacak, yeni öğrenme yöntemleri tasarımını gerçekleştirebilecek gerçek eğitim liderleri olarak yetişebilirler (Demirci, 2008: 181). Eğitim sisteminin ve eğitim kurumlarının başarısı, söz konusu sistemin uygulayıcısı olan öğretmenlerin niteliğine bağlıdır. Hiçbir eğitim modeli o modeli işletecek personelin niteliğinin üzerinde hizmet üretemez. Bir okul ancak öğretmenleri ölçüsünde iyidir. Eğitimin kalitesi en iyi öğretmenleri meslekte tutmaktan geçer.

TKY yaklaşımının ne olup olmadığı konusunda okul yönetici ve öğretmenlerinin eğitilmesi gereklidir. Bu eğitimin içeriği, TKY'nin felsefesini, öne çıkardığı kavram ve değerleri, bu bağlamda geliştirilen yöntem ve teknikleri kapsamalıdır. Bu amaçla geliştirilecek bir eğitim programında yer alması öngörülen başlıca konular olarak, bir yaşam alanı olarak okul ve okul yönetim süreçleri, okul-çevre ilişkileri, etkili çalışma ekipleri oluşturma, çalışanların ve 
müşterilerin beklenti ve memnuniyetlerini en üst düzeye çıkarmak ve etkili sonuçlar elde edebilmek için yapılması gerekenleri içermelidir. (Yıldız, 2006: 29). Bu eğitim süreci, katılımcılara, okul yaşamı, çalışma yaşamı, insan ve hayata ilişkin olarak yeni bakış açıları kazandırmalıdır.

\section{Okul Kalite Geliştirme Kurulunun Oluşturulması}

TKY, büyük ölçüde ekip çalışmasına dayalı bir yaklaşımdır. Dolayısıyla her aşamada belirli amaçlarla oluşturulmuş ekiplerin kurulması ve işletilmesi gerekli olmaktadır. Bunlardan birisi de okul kalite geliştirme kuruludur. Bu kurul, okul yönetiminde TKY'ye geçiş sürecinde bir üst kurul olup, bu kurulda yer alacak üyelerin öncelikle TKY konusunda eğiticilerin eğitimi için düzenlenecek eğitim programlarına katılmış ve bu konuda bilgi sahibi kişiler olması gereklidir. $\mathrm{Bu}$ üyeler, eğitimin üretiminde ve tüketiminde müşteri konumunda olan herkesten olabilir. Bu kurul, yönetilebilir ve yönetebilir bir büyüklükte 5-10 üyeden oluşabilir. Bu kurulun temel görevi, TKY'ni okula uygulamak ve etkili sonuçlar almak değil, TKY ile ilgili danışmanlık ve politika belirleme hizmetlerini yürütmek olmalıdır. Okuldaki meslek dersi öğretmenlerinin sayısı 6' dan az ise bunların tamamı KGK' ya üye olabilir. Daha fazla sayıda meslek dersi öğretmeni olan okullarda ise KGK' ya seçilecek öğretmen sayısı, KGK'ya üye olmak için istekli olan öğretmen sayısı ve toplam öğretmen sayısı dikkate alınarak belirlenir. (Şişman ve Turan, 2002: 60).

Kalite Geliştirme Ekipleri (KGE), KGK tarafından hazırlanan okul kalite planı çerçevesinde belirlenen iyileştirme faaliyetlerinin yürütülmesinden sorumlu ekiplerdir. Kısaca, iyileştirme yapılacak konular ve bu iyileştirmelerin gerçekleştirilmesi için yapılacak işlemler Kalite Geliştirme Kurulu tarafindan belirlenir, KGE ise Kalite Geliştirme Kurulu Tarafindan belirlenen işlemleri gerçekleştirmekle görevlidir. TKY'nin temel değerlerinden birisi, demokratik katılım ve birlikte sorun çözmedir. Okula ilişkin her türlü problemlerin belirlenmesi ve çözümü için belirli ekiplerin oluşturulması kaçınılmazdır. Bu, şu anlama gelmektedir: Okula ilişkili olan bütün çalışanların okula ilişkin görüşlerinin alınması ve değerlendirilmesi, hem çalışanların memnuniyeti hem de müşteri memnuniyeti açısından hayati bir önem taşımaktadır. (Ensari, 2003: 198). TKY, sürekli sorun belirleme ve sorun çözme süreci olduğundan, okulun çeşitli alanlarına ve konularına dönük olarak sorun belirleme ve çözme ekiplerinin oluşturulması gerekmektedir. Bu aşamada Kalite Geliştirme Kurulu, planlama dönemi başında yapılan okul değerlendirmesi ile 
dönem sonunda yapılan okul değerlendirilmesi sonuçlarını karşılaştırır ve okul kalite planının uygulanması neticesinde nelerin başarıldığını, nelerin başarılamadığını, başarısızlık nedenlerini ve de başarısız olunan konularla ilgili nelerin yapılabileceğini belirler. Bunların yapılabilmesi için, dönem başı ve dönem sonunda yapılan değerlendirmelerin sonuçlarının karşılaştırılmass gerekir. Okul profilinin çıkarılması ya da okulun kendini bir öz değerlendirmeye tabi tutması, iki temel boyutta düşünülebilir: Bunlardan birincisi, okulun iç çevresi, diğeri ise dış çevre yönündendir. İç çevre, okulun hâlihazırda sahip olduğu eğitim programlarını ve bunların, öğrencilere nasıl sunulmakta olduğunu, okulun kültürü (okulun vizyonu, misyonu, amaçları, değerleri vb.), öğretim kadrosu ve çalışanların profilinin çıkarılması (eğitim düzeyleri, işgücünün çeşitliliği, istihdam biçimleri vb.), okulun kullandığı fiziki mekânlar, teknolojiler, araç-gereçler vb., okulun uymak durumunda olduğu yasal çerçeve zorunlu yasalar, yönetmelikler, programlar, mali kaynakların sağlanma ve kullanılmasına ilişkin esaslar gibi öğeleri kapsamaktadır. İkinci boyut ise dış çevredir. Burada üzerinde durulması gereken temel nokta, eğitim hizmetini almak üzere okula gelenler ve bunların mezuniyetten sonra piyasadaki durumudur. Burada üzerinde durulması ve analiz edilmesi gereken diğer önemli bir nokta da okulun kendi kategorisi içinde yer alan diğer okullarla karşılaştırılması, bir bakıma rakiplerin belirlenmesidir. (Aydın, 2007: 70). Buna bağlı olarak okulun, mezunları için gerekli olan temel nitelikleri ne ölçüde kazandırdığının ve mezunlarının nerelere gittiğinin, nasıl istihdam edildiklerinin belirlenmesi, mezunların izlenmesi, onlarla ne ölçüde karşılıklı iletişimde bulunulduğunun belirlenmesi gerekmektedir.

\section{Okul Yöneticilerinin Önderlik Etme Özellikleri}

Genel olarak, eğitsel liderlik, okulun ve yöneticinin sorumluluğu olarak görülmektedir: Oysa toplam kalite yaklaşımında liderlik, ilgili örgütteki ya da alandaki herkesin sorumluluğudur. Böyle bir yaklaşımı benimsemiş bir eğitim kurumunda da, yöneticiler, öğretmenler ve diğer çalışanlar kararlar vermekten çekinmezler; onların katkıları ve önerileri memnuniyetle karşılanır ve istenir. Ancak böyle bir eğitim kurumunun öğrencileri, herkese potansiyelinin en üst sınırına erişebilmesini sağlayacak, yeni öğrenme yöntemleri tasarımını gerçekleştirebilecek gerçek eğitim liderleri olarak yetişebilirler.

TKY sürecinin her aşamasında okul yöneticilerinin liderliği olmadan TKY'nin okul yaşamında uygulanabilmesi olanaklı değildir. Liderlik, TKY'nin en önemli öğelerinden biridir. Okul 
yöneticilerinin liderliği olmadan TKY'nin başlatılabilmesi de mümkün değildir. Lider, TKY kültürünü oluşturan, geliştiren ve yücelten kişidir (Başar, 2005: 153-159). Bir lider olarak okul yöneticilerinden bu süreçte beklenenler, katılımı sağlama, destekleme, kendini okula adama, insanların başarı ve çalışmalarını takdir etmedir. Okul müdüründen, bir eğitim ve öğretim lideri olarak okul tarafından belirlenen stratejik amaçları, okul vizyon ve misyonunu gerçekleştirme, örgütsel performansı en üst düzeye çıkarması beklenmektedir.

\section{Sonuç}

Eğitim yönetiminde Toplam Kalite Yönetimi Uygulamalarının Okul Yöneticileri tarafından değerlendirilmesine yönelik olarak yapılan bu çalışma Millî Eğitim sisteminin işleyişi hakkında tatmin edici sonuçlar doğurmuştur.

Toplam Kalite Yönetimi okul yöneticileri için ayrı fedakârlık yapmalarını gerektiren bir çalışmadır. Bu sebeple başarılı olsun olmasın hakkıyla yapılan her Toplam Kalite Yönetimi çalışması takdir edilmelidir. Böylece çalışanlara zor ve karmaşık gelen Toplam Kalite Yönetimi uygulamalarında çalışanların motivasyonları artırılmış olur.

Eğitim yöneticilerinin bu bağlamda alt yapı ile ilgili yetersizlikten kaynaklı isteklerini tespit edecek araştırmalar yapılmalı ve TKY uygulamaları için eğitim kurumları yeterli donanıma kavuşturulmalıdır. Bu ve benzeri çalışmalar tüm ülkeyi kapsayacak şekilde ve çok daha nitelikli tarzda genişletilmelidir.

TKY uygulamalarında eğitimin önemi tartışılmazdır. Uygulamalar basit ve anlaşılır düzeye indirilmeli, eğitimlerin nitelikleri ve özellikleri gözden geçirilmelidir. Bu anlamda; geniş zamanlı, öğretmenlere ve yöneticilere felsefe ve uygulamaların kavratıldığ güncel ve kesintisiz eğitimler verilebilir; eğitimler uygulamaya dönük olabilir, örnek okul incelemeleri yapılabilir; karmaşıklık yaratan konular tespit edilebilir, bu doğrultuda düzenlemeler yapılabilir.

TKY uygulamaları ile ilgili olarak İl ve İlçe Milli Eğitim Müdürlüklerinde var olan koordinasyon büroları etkin hale getirilmelidir. Ayrıca burada tam zamanl, konunun uzmanı, okullara destek olabilecek personel bulunmalıdır.

Veli ve öğrencinin kalite konusunda bilgilendirilmesi, sınıf veli toplantılarının, öğrenci okul meclislerinin gündem maddeleri arasında yer almalıdır. TKY çalışmaları kendi kısır döngüsünden çıkarılıp içine veli ve öğrenciyi de alarak genişletilmelidir. Bunun için velileri ve öğrencileri içine 
alan eğitim programları düzenlenmelidir.

TKY eğitimlerinde TKY'nin felsefesi üzerinde ayrıca durulmalı, eğitimler bu felsefe üzerine düzenlenmelidir. Çalışanlardaki TKY ile ilgi önyargıları ortadan kaldıracak TKY'nin önemini kavratıcı eğitimler verilmelidir. TKY çalışmalarını zorunluluktan çok insanların severek yaptığı iş haline getirmek için düzenlemeler yapılmalıdır. Örneğin bu çalışmalarda yer alanlara ek ders ücreti ödenmesi, çeşitli ödüller verilmesi gibi.

TKY uygulamalarında kilit rol oynayan lider yönetici tutumlar geliştirilmeli. TKY açısından bu yöneticiler donanımlı hale getirilmelidir. Okullarda oluşturulan kurulların göstermelik olmaktan çıkarılıp daha işlevsel olması için çalışmalar yapılmalıdır.

\section{Kaynakça}

Adem, M. (1997). Eğitim Planlaması (3. Baskı). Ankara: Şafak Matbaacılık.

Akbulut Taş, M. (2004). Eğitimde Toplam Kalite Yönetim Anlayışına Göre Hizmet İçi Eğitime Katılan Öğretmen Ve Yöneticilerin İş Motivasyonuna İlişkin Durum Ve Görüşlerinin Araştırılması. Yayınlanmamış Yüksek Lisans Tezi. Çukurova Üniversitesi, Sosyal Bilimler Enstitüsü.

Aydın, M. (2007). Eğitim Yönetimi. (8. Baskı). Ankara: Hatiboğlu Yayıncılık.

Başar, H. (2000). Eğitim Denetçisi. (5. Baskı). Ankara: PegemA Yayıncılık.

Başaran, İ. E. (1989). Yönetim. (2. Baskı). Ankara: Kadığlu Matbaası.

Başaran, İ. E. (1991). Örgütsel Davranış. Ankara: Kadığglu Matbaası.

Başaran, İ. E. (2004). Yönetimde İnsan İlişkileri. (3.Baskı). Ankara: Nobel Yayınları.

Baykara, S. (1999). Eğitimde Toplam Kalite Yönetiminin Uygulanabilirliği Ve Bir Model Önerisi.

Yayımlanmamış Yüksek Lisans Tezi. Afyon Kocatepe Üniversitesi, Sosyal Bilimler Enstitüsü.

Bursalığlu, Z. (2005a). Eğitim Yönetiminde Teori ve Uygulama. (8. Baskı). Ankara: PegemA Yayınc1lik.

Çağlar, M. ve Reis, O. (2007). Eğitimde Paradigmal Dönüşümler Sürecinde Çağdaş Ve Küryerel Eğitim Planlaması. Ankara: PegemA Yay.

Çakıl, R. Z. (2006). Eğitimde Toplam Kalite Yönetimi - İstanbul İlçe Milli Eğitim Müdürlerinin Eğitimde Kaliteyi Algılayış Düzeyleri. Yayımlanmamış Yüksek Lisans Tezi, 
Marmara Üniversitesi, Sosyal Bilimler Enstitüsü.

Çetin, C., Akın, B. ve Erol, V. (2001). Toplam Kalite Yönetimi Ve Kalite Güvence Sistemi (ISO 9000-2000 Revizyonu) İlke - Süreç - Uygulama. İstanbul: Beta Basım Yayım.

Demirci, H. (2008). Toplam Kalite Yönetimi. İstanbul: Kum Saati Yayınları.

Demirel, Ö. ve Kaya, Z. (2004). Eğitimle İlgili Temel Kavramlar. Öğretmenlik Mesleğine Giriş. (5. Baskı). Ankara: PegemA Yayıncilık.

Dewey, J. (2008). Okul ve Toplum. Ankara: Pegem Akademi.

Dewey, J. (1994). Yeni Gerçekler. (4. Baskı). Ankara: İş Bankası Kültür Yayınları.

Doğan, E. (2002). Eğitimde Toplam Kalite Yönetimi. Ankara: Academyplus Yayınevi.

Doğan, E. (2003). Eğitimde Toplam Kalite Yönetimine Geçiş. Ankara: Anı Yayıncılık.

Doğan, S. (2003). Personel Güçlendirme. İstanbul: Sistem Yayıncılık.

Dökmen, Ü. (2005). İletişim Çatışmaları ve Empati. (31. Baskı). İstanbul: Sistem Yayıncılık.

Dökmen, Ü. (2009). Evrenle Uyumlaşma Sürecinde Varolmak, Gelişmek, Uzlaşmak. (12. Baskı). İstanbul: Remzi Kitabevi.

Ensari, H. (2003). 21.yy. Okulları İçin Toplam Kalite Yönetimi. (4. Bask1). İstanbul: Sistem Yayıncilik.

Ensari, H. (2010). 21. yy. İçin Çağdaş Bir Yönetim Yaklaşımı: Toplam Kalite Yönetimi. 21. yy.'da

Eğitim ve Türk Eğitim Sistemi. (Ed. Oğuz, O - Oktay, A. ve Ayhan, H.). Ankara: Pegem Akademi. 115-147.

Erdoğan, İ. (2004). Eğitimde Değişim Yönetimi. 2.Baskı. Ankara: Pegem Yayıncılık.

Ergit, Ş. (2000). Milli Eğitim ile İlgili Mevzuat. İstanbul: MEB Basımevi.

Eroğlu, E. (2000). Sürekli Kalite İyileştirme İlkelerinin Temel Eğitimde Uygulanması. Pamukkale Üniversitesi Dergisi, Say1: 7, 167-175.

Gülsoy, R. G. (2007). İlköğretim Okullarında Toplam Kalite Yönetiminin Uygulanabilirliği. Yayımlanmamış Yüksek Lisans Tezi, Yeditepe Üniversitesi.

Halis, M. (2000). Paradigmadan Uygulamaya Toplam Kalite Yönetimi Ve ISO 9000 Kalite Güvence Sistemleri: ISO 9002 Kalite Belgesi Çalışmaları. İstanbul: Beta Basım.

İnce, C. (2008). Toplam Kalite Çerçevesinde İşgörenlerin Otel İşletmelerinden Memnuniyetleri Ve Sonuçları Üzerine Nevşehir Yöresindeki 4 Ve 5 Yıldızlı Otel İşletmelerinde Bir Araştırma. III. Balıkesir Ulusal Kongresi Bildiriler Kitabı, Ankara: Nobel Yayın 
Dağıtım.

Kaya, Y. K. (1984). Eğitim Yönetimi, Kuram ve Türkiye'deki Uygulama. (2.Baskı). Ankara: TODAİE Yayınları.

Meder, M. (2001). Bilgi Toplumu ve Toplumsal Değişim. Pamukkale Üniversitesi Ĕ̌itim Fakültesi Dergisi, Say1: 9, 72-81.

Özdemir, S. M. (2005). Eğitim Kurumlarında Toplam Kalite Yönetimini Olumsuz Etkileyen Etmenler. Gazi Ĕ̆itim Fakültesi Dergisi, Sayı: 3, 1-23.

Şahin, İ. (2006). İlköğretim Müfredat Laboratuar Okullarının Okul Geliştirme Süreci Açısından İncelenmesi. Yayımlanmamış Doktora Tezi. Dokuz Eylül Üniversitesi, Eğitim Bilimleri Enstitüsü.

Şen, H. Ş. ve Erişen, Y. (2002). Öğretmen Yetiştiren Kurumlarda Öğretim Elemanlarının Etkili Öğretmenlik Özellikleri. Gazi Eğitim Fakültesi Dergisi, Sayı: 1, 99-116.

Şişman, M. (1994). Örgüt Kültürü. Eskişehir: A.Ü. Eğitim Fakültesi Yayınları.

Şişman, M. ve Turan, S. (2002). Eğitimde Toplam Kalite Yönetimi. (2. Baskı). Ankara: PegemA Yayınc1lik.

Şişman, M. (2002). Eğitimde Mükemmellik Arayışı. Ankara: Pegem Yayıncılık.

Türkmen, Ö. (2006). İlköğretim Okullarında Toplam Kalite Yönetimi Uygulamalarına İlişkin Müdür Ve Öğretmen Görüşlerinin Değerlendirilmesi, Yayımlanmamış Yüksek Lisans Tezi, Dicle Üniversitesi.

Kalite Yönetimi İlköğretim ve Ortaöğretim Kurumlarında TKY Uygulama Modeli. Ankara: Nobel Yayın Dağıtım.

Yaşar, M. (2003). Ortaöğretim Okul Yöneticilerinin Yönetimsel Uygulamalarının Toplam Kalite Açısından Değerlendirilmesi. Yayımlanmamış Doktora Tezi. Gaziantep Üniversitesi, Sosyal Bilimler Enstitüsü.

Yeşilbayır, S. (2007). Toplam Kalite Yönetimi. Yayımlanmamış Yüksek Lisans Tezi, İstanbul Teknik Üniversitesi.

Yıldırım, C. (2008). İlköğretim Okulu Öğretmen Ve Yöneticilerinin Öğretmenlerin Ödüllendirilmesine İlişkin Görüşleri. Kuram ve Uygulamada Ĕ̆itim Yönetimi Dergisi, Say1: 56, 663-690.

Yıldırım, H. A. (2002). Eğitimde Toplam Kalite Yönetimi. Ankara: Nobel Yayın Dağıtım. Yıldız, E. (2006). İlköğretim Okullarında Toplam Kalite Yönetimi: İskenderun Örneği. 
Yayımlanmamış Yüksek Lisans Tezi. Mustafa Kemal Üniversitesi, Sosyal Bilimler Enstitüsü.

Yıldız, S. M., Erdemir, İ. ve Gitmez, M. (2006). Bir Orta Öğretim Kurumunda Toplam Kalite Yönetimi Uygulamalarının Öğrenci Memnuniyeti Üzerine Etkisinin İncelenmesi. Milli Ĕ̈itim Dergisi, Say1: 172, 143-154. 